Abstracta Iranica

Revue bibliographique pour le domaine irano-aryen

Volume 28 | 2007

Comptes rendus des publications de 2005

\title{
Gnostic Ethic and Mandaean Origins. Piscataway, Gorgias, 2004, 102 p.
}

Christelle Jullien

\section{(2) OpenEdition \\ 12 Journals}

Édition électronique

URL : http://journals.openedition.org/abstractairanica/12302

DOI : 10.4000/abstractairanica. 12302

ISSN : 1961-960X

\section{Éditeur :}

CNRS (UMR 7528 Mondes iraniens et indiens), Éditions de l'IFRI

\section{Édition imprimée}

Date de publication : 15 mai 2007

ISSN : 0240-8910

\section{Référence électronique}

Christelle Jullien, «Gnostic Ethic and Mandaean Origins. Piscataway, Gorgias, 2004, 102 p. », Abstracta Iranica [En ligne], Volume 28 | 2007, document 257, mis en ligne le 18 septembre 2007, consulté le 25 septembre 2020. URL : http://journals.openedition.org/abstractairanica/12302 ; DOI : https://doi.org/ 10.4000/abstractairanica.12302

Ce document a été généré automatiquement le 25 septembre 2020.

Tous droits réservés 


\title{
Gnostic Ethic and Mandaean Origins. Piscataway, Gorgias, 2004, 102 p.
}

\author{
Christelle Jullien
}

La première édition de ce livre remonte à 1970. Cette nouvelle version propose neuf nouvelles pages introductives qui restituent ce travail dans le contexte des publications récentes sur le gnosticisme et le mandéisme. Plusieurs thèmes sont abordés dans le corps de l'ouvrage : les textes gnostiques mandéens, les textes gnostiques coptes, les parallèles copto-mandéens, l'éthique gnostique, l'éthique mandéenne, la question des origines juives du mandéisme; suivent une présentation des sources et quelques interrogations. Yamauchi propose plusieurs hypothèses: les mandéens ne seraient apparus qu'au $\mathrm{II}^{\mathrm{e}} \mathrm{s}$. de notre ère; leurs opinions sur le mariage les distinguent $\mathrm{du}$ comportement et de la conduite d'autres groupes; selon lui, leur théologie gnostique aurait été transmise par migration depuis les bords du Jourdain jusqu'en Mésopotamie où elle fut mêlée à un culte indigène; enfin, ce serait grâce à leur longue et solide tradition rituelle qu'ils auraient survécu.

\section{INDEX}

Thèmes : 6.3. Autres religions

\section{AUTEURS}

CHRISTELLE JULLIEN

CNRS / Mondes iranien et indien - Paris 